\title{
Development of Colonization/Infection with Carbapenem Resistant Klebsiella pneumoniae and Distribution of Carbapenemase Types in Adult Intensive Care Units
}

öz

Karbapenem dirençli Enterobacteriaceae üyelerinin neden olduğu enfeksiyonların sıklığı tüm dünyada giderek artmakta olup mortalite oranları oldukça yüksektir. Bu kökenler ile oluşan enfeksiyonların ve kolonize hastaların hızlı tespiti, enfeksiyon kontrol protokollerinin uygulanması açısından oldukça önemlidir. Çalışmamızda erişkin yoğun bakım ünitelerinde yatan hastalarda karbapenem dirençli Klebsiella pneumoniae kökenleri ile gelisen kolonizasyon/enfeksiyon oranları ve karbapenemaz tiplerinin arastırılması amaçlanmıştır. Bu çalışmaya erişkin yoğun bakım ünitelerinde yatan hastalardan Haziran-Aralık 2017 tarihleri arasında rektal sürüntü örneklerinden ve klinik örneklerden izole edilen karbapenem dirençli K.pneumoniae (KD-Kp) kökenleri dahil edilmiştir. Kökenlerin antibiyotik duyarlııkları VITEK2 otomatize sistemi ile çalıssılmıştır. Karbapenemazların fenotipik tespitinde NG CARBA-5 immunokromayöntemi üreticinin önerileri doğrultusunda çalısılmıștır. Karbapenemaz genlerinin (OXA-48, IMP, VIM, $K P C, N D M)$ varlı̆̆ı spesifik primerler kullanılarak PCR yöntemi ile araștırılmıştır. Çalışma süresi içerisinde 344 hastaya ait tarama kültüründen 51 adet ve aynı döneme ait klinik örneklerden 30 adet KD-Kp üremistir. Hastaların en az ücte birinde birden fazla gen pozitifliği gözlemlenmiștir. Enfeksiyon gelișen 17 hastanın geçmiş üç ay içerisinde bu mikroorganizma ile kolonize olduğu saptanmıştır. Enfeksiyon saptanan 4 hastanın tarama kültürleri negatif iken 9 hastada tarama kültürü olmaksızın KD-Kp enfeksiyonu gelismistir. Buna göre yoğun bakım ünitelerimizde kolonizasyon/enfeksiyon oranı \%33,3 saptanmıștır. Yoğun bakım ünitelerimizde OXA-48 ve NDM türü enzimler \% 60'lar düzeyindedir. Ilginç olan daha önceki yıllarda gözlemlemediğimiz KPC tipi enzimin hem klinik hem de tarama kültürlerinden saptanmış olmasıdır. Yoğun bakım ünitelerimizde enfeksiyon/kolonizasyon oranı azımsanmayacak düzeyde olup kolonize hastaların yaklaşık üçte birinde enfeksiyon gelişebileceği belirlenmiştir.

Anahtar kelimeler: Karbapenemaz, Klebsiella pneumoniae, kolonizasyon/enfeksiyon

\section{ABSTRACT}

The incidence of infections caused by carbapenem-resistant Enterobacteriaceae is increasing worldwide and, mortality rates are high. Rapid detection of infections and colonized patients with these strains is very important for the implementation of infection control protocols. In this study, we aimed to investigate the colonization/infection rates and carbapenemase types due to carbapenem-resistant Klebsiella pneumoniae in patients hospitalized in adult intensive care units. Carbapenem-resistant K.pneumoniae (CRKP) strains isolated from the rectal swab and clinical samples between JuneDecember 2017 from patients hospitalized in adult intensive care units were included in this study. Antibiotic susceptibility of the strains was studied by VITEK2 automated system. In the phenotypic determination of carbapenemases, NG CARBA-5 immunochromatographic method was studied according to the manufacturer's recommendations. The presence of carbapenemase genes (OXA-48, $I M P, V I M, K P C, N D M)$ was investigated by PCR method using specific primers. During to study period, 51 $C R-K p$ from the screening culture of 344 patients and 30 CR-Kp from clinical samples were produced. More than one gene positivity was observed in at least one-third of the patients. Seventeen patients who developed infection were colonized with this microorganism in the past three months. Four patients with infection had negative screening cultures, while nine patients developed CRKP infection without screening culture. Accordingly, colonization/infection rate in our intensive care units was determined as $33.3 \%$. In our intensive care units, OXA-48 and NDM enzymes are $60 \%$. Interestingly, the KPC type enzyme, which we did not observe in previous years, was detected from both clinical and screening cultures. The infection / colonization rate in our intensive care units is not negligible and, approximately one third of colonized patients may develop the infection.

Keywords: Carbapenemase, colonization/infection, Klebsiella pneumoniae

(C) Telif hakkı Antibiyotik ve Kemoterapi (ANKEM) Derneği'ne aittir. Logos Tıp Yayınclık tarafindan yayınlanmaktadır. Bu dergide yayınlanan bütün makaleler Creative Commons Attf-Gayri Ticari 4.0 Uluslararası Lisansı ile lisanslanmıştır.

(c) Copyright Society of Antimicrobial Chemotherapy. This journal published by Logos Medical Publishing.

Licenced by Creative Commons Attribution-NonCommercial 4.0 International (CC BY-NC 4.0)
Alındığı tarih: 14.10 .2019

Kabul tarihi: : 05.12.2019

Yayın tarihi: 30.12 .2019

Gülşen Altınkanat

Marmara Üniversitesi Tıp Fakültesi Tıbbi Mikrobiyoloji Anabilim Dalı Karabük - Türkiye

gulsenaltinkanat@yahoo.com ORCID: 0000-0003-0274-628X

U. Hasdemir 0000-0002-1606-0804 G. Söyletir 0000-0001-5695-731X Marmara Üniversitesi Tıp Fakültesi

Tıbbi Mikrobiyoloji Anabilim Dalı Karabük - Türkiye

* 13. Antimikrobiyal Kemoterapi Günleri'nde sunulmuştur. Poster No:56 (6-8 Nisan 2018, istanbul) 
G. Altınkanat Gelmez ve ark., Erişkin Yoğun Bakım Ünitelerinde Karbapenem Dirençli Klebsiella pneumoniae ile Kolonizasyon/Enfeksiyon Gelişimi ve Karbapenemaz Tiplerinin Dağılımı

\section{Giriş}

Gram negatif bakterilerle gelişen enfeksiyonların tedavisinde son seçenek antibiyotikler arasında yer alan karbapenemlerin sıklıkla kullanımı beraberinde karbapenem direncinde önemli artışa neden olmuştur. Enterobacteriaceae üyelerinde karbapenem direncinin en önemli sebebi karbapenemleri hidroliz eden bir karbapenemaz üretimidir. Sınıf A (KPC, GES, SME vb), sınıf $B$ (IMP, VIM, NDM) ve sinıf D (OXA-23, OXA-24, OXA-58, OXA-48) karbapenemazların prevalansları coğrafik olarak farklılık göstermekle beraber tüm dünyada yaygın olarak görülmektedirler ${ }^{(16)}$.

Karbapenem direncindeki hızlı artışın en önemli sebebi karbapenemazları kodlayan genetik elemanların plazmid aracılığıyla türler arasında hızlı yayılımıdır. KPC; Amerika, Güney Avrupa, İsrail, Çin'in bazı bölgelerinde, NDM; İngiltere ve Hindistan başta olmak üzere kuzey Avrupa ve Asya pasifik bölgelerinde endemiktir. Üçüncü en sıklıkla gözlemlenen OXA-48 karbapenemazlar başta Türkiye olmak üzere Kuzey Afrika ve Avrupa'da endemiktir. Daha az sıklıkla gözlemlenen VIMve IMP tipi metallo-beta laktamazlar Yunanistan, Japonya ve Çin gibi ülkelerden rapor edilmektedir ${ }^{(16,10)}$.

Dünya Sağlık Örgütünün halk sağlığını tehdit eden mikroorganizmalar sınıflandırmasında karbapenem dirençli Enterobacteriaceae (KDE) üyeleri birinci sırada yer almaktadır. Başta Klebsiella pneumoniae olmak üzere Enterobacteriaceae üyelerinde 2000'li yıllarda nadir gözlemlenen karbapenem direnci, son yıllarda hızlı bir artış göstermiştir. Gerek enfeksiyon riski gerekse mortalite oranları özellikle yoğun bakımda tedavi gören hastalarda, immunkompromize hastalarda ve organ nakli alıcılarında oldukça yüksektir. Gastrointestinal taşıyıcılık, özellikle hastane ortamında çapraz bulaş kaynağının en önemli sebeplerinden biridir. Endemik olan bölgelerde hastanede yatan hastalarda kolonizasyon oranı \% 3-7 arasında değişmekle beraber, yoğun bakım hastalarında bu oran oldukça yüksektir ${ }^{(2,3,4,17,18,19)}$. KDE ile kolonizasyon, enfeksiyon gelişiminde bilinen önemli risk faktörlerinden biridir.
Yapılan araştırmalarda yoğun bakım ünitelerinde yatan KDE ile kolonize olan hastalarda enfeksiyon gelişme riskinin \% 29-73 arasında değiştiği, mortalite oranlarının ise \% 26-44 oranında arttığı belirlenmiştir $^{(6,7,8,12)}$. Bu kökenler ile oluşan enfeksiyonların ve kolonize hastaların tespiti, enfeksiyon kontrol protokollerinin uygulanması açısından oldukça önemlidir. Kullanılacak yöntem her ne olursa olsun temel hedef bu patojenlerin neden olduğu enfeksiyonların daha iyi yönetilebilmesi ve yayılımlarını önlenmek için karbapenemaz üreten Enterobacteriaceae kökenlerin hızlı tespitidir.

Çalışmamızda erişkin yoğun bakım ünitelerinde yatan hastalarda karbapenem dirençli K.pneumoniae kökenleri ile gelişen kolonizasyon/enfeksiyon oranları ve karbapenemaz tiplerinin araştırılması amaçlanmıştır.

\section{GEREÇ VE YÖNTEM}

Kökenlerin Seçimi ve İdentifikasyonu: Marmara Üniversitesi Pendik Eğitim ve Araştırma Hastanesi erişkin yoğun bakım ünitelerinde yatan hastalardan Haziran-Aralık 2017 tarihleri arasında karbapenemaz tarama amacıyla gönderilen rektal sürüntü örneklerinden ve aynı tarih aralığında klinik örneklerden (kan, derin trakeal aspirat, bronkoalveolar lavaj, batın içi abse, doku) izole edilen karbapenem dirençli K.pneumoniae kökenleri çalışmaya dahil edilmiştir. Çalışma süresince 344 hastadan alınan rektal sürüntü örnekleri kromojenik bir besiyeri olan chromID CARBA'ya (bioMérieux, Fransa) ekilip bir gece $37^{\circ} \mathrm{C}^{\prime}$ de inkübe edilmiştir. İnkübasyon sonrası üreyen koloniler VITEK MS (bioMérieux, Fransa) otomatize sisteminde tanımlanmıştır. Laboratuvarımıza kültür işlemleri için gönderilen diğer klinik örneklerin ekimleri ise uygun besiyerlerine yapıldıktan sonra enfeksiyon etkeni olarak düşünülen mikroorganizmalar VITEK MS (bioMérieux, Fransa) otomatize sisteminde tanımlanmıştır.

Antibiyotik Duyarlılıkları: Rektal sürüntü ve klinik örneklerden üretilen K.pneumoniae kökenlerinin antibiyotik duyarlııkları VITEK2 (bioMérieux, Fransa) otomatize sistemi ile çalışılmıştır. EUCAST 
önerileri doğrultusunda karbapenemlerden (imipenem, ertapenem, meropenem) en az birine dirençli saptanan kökenlerde karbapenemaz varlığının araştırıması için fenotipik ve genotipik yöntemler kullanılmıştır(9).

\section{Karbapenemazların fenotipik tespiti:} Antibiyotik duyarlılık test sonuçlarına göre, karbapenemlerden en az birine dirençli olarak saptanan K.pneumoniae kökenlerinde OXA-48, NDM, KPC, IMP ve VIM tipi karbapenemazların fenotipik tespitinde NG CARBA-5 (NG Biotech, Fransa) immunokromatografik yöntemi kullanılmıştır. Üreticinin önerileri doğrultusunda \% 5 koyun kanlı agar'da 18-24 saat inkübe edilen kökenlerden $1 \mu^{\prime}$ lik öze ile alınan koloniler $150 \mu$ lizis solüsyonunda süspanse edilmiştir. Süspansiyondan $100 \mu \mathrm{l}$ NG CARBA5 (NG Biotech, Fransa) test kasetine eklenerek $15 \mathrm{dk}$. oda ısısında inkübe edilmiştir. İnkübasyon sonrası test ve kontrol bantları değerlendirilmiştir.

Karbapenemaz genlerinin tespiti: Çalışmaya dahil edilen K.pneumoniae kökenleri \% 5 koyun kanlı agara pasajlanıp bir gecelik inkübasyona bırakılmıştır. DNA izolasyonu için, inkübasyon sonrası üreyen kolonilerden 2-3 adet alınıp $250 \mu$ distile su içerisinde bakteri süspansiyonu hazırlanarak $95^{\circ} \mathrm{C}^{\prime} \mathrm{de} 10 \mathrm{dk}$ ısıtılmıştır. Bakteri süspansiyonu 5 dk 13,000 x g'de santrifüj edildikten elde edilen süpernatan polimeraz zincir reaksiyonunda (PZR) kalıp DNA olarak kullanılmıştır. Karbapenemaz (blaOXA-48, blaıMP, blaVIM, blaKPC, blaNDM) genlerinin varlığı spesifik primerler kullanılarak polimeraz zincir reaksiyonu ile

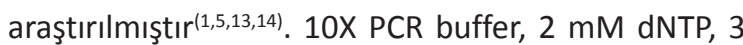
pmol primer, 2,5 mM MgCl2, $1 \cup$ Taq DNA polimeraz ve $2 \mu$ l of genomik DNA içeren $50 \mu$ l'lik PZR karışımı hazırlanıp her gen için uygun reaksiyon koşulları kullanılarak amplifikasyon gerçekleştirilmiştir. Elde edilen PCR ürünleri etidyum bromid içeren \% 1'lik agaroz jelde 90 V'da 1 saat yürütülerek UV ışık altında oluşan bantlar analiz edilmiştir.

\section{BULGULAR}

Çalışma süresi içerisinde 344 hastaya ait tarama kültüründen 51 adet ve aynı döneme ait klinik örneklerden 30 adet karbapenem dirençli K.pneumoniae üretilmiştir. Tarama ve kültür izolatlarında saptanan karbapenemaz türleri Tablo 1'de verilmiştir. İzolatların en az üçte birinde (klinik \% 33.3, tarama \% 47) birden fazla karbapenemaz gen pozitifliği gözlemlenmiştir (Tablo 1). En sık karşılaşılan karbapenemaz enzimlerinin OXA-48 ve NDM olduğu belirlenmiştir. Çalışma sırasında fenotipik yöntem olarak kullanılan NG CARBA sonuçları PZR sonuçları ile \% 100 uyumlu bulunmuştur. Enfeksiyon gelişen 17 hastanın geçmiş üç ay içerisinde bu mikroorganizma ile kolonize olduğu saptanmıştır. Bu hastaların yedisinde kan dolaşımı enfeksiyonu, sekizinde solunum yolu enfeksiyonu ve ikisinde intraabdominal enfeksiyon gelişmiştir. Enfeksiyon gelişen 4 hastanın tarama kültürleri negatif iken 9 hastada tarama kültürü olmaksızın karbapenem dirençli K.pneumoniae enfeksiyonu gelişmiştir (Tablo 2). Buna göre yoğun bakım ünitelerimizde karbapenemaz-pozitif K.pneumoniae kolonizasyon oranımız \% 14.8, kolonizasyon/enfeksiyon oranımız ise \% 33.3 saptanmıştır. Enfeksiyon gelişen hastalardan ( $n=17)$ izole edilen kökenler ile tarama kökenlerinin enzim profilleri 16 hastada (\% 94.1) aynı saptanmış, 1 hastada ise tarama kültüründe KPC+NDM birlikteliği var iken klinik kökende sadece KPC pozitifliği saptanmıştır.

\section{TARTIŞMA}

Karbapenemler de dahil olmak üzere çoğu beta laktamı hidroliz edebilen karbapenemazlar Enterobacteriaceae üyeleri arasında yıllar içerisinde hızı bir yayılım göstermiştir. Beta laktam haricinde diğer sınıf antimikrobiyallere karşı direncin sıklıkla gözlemlenmesi bu kökenlerle gelişen enfeksiyonların tedavisinde kullanılacak antimikrobiyalleri kısıtlamaktadır. Yeni geliştirilmekte olan antimikrobiyallerin azlığı nedeniyle gelişen enfeksiyonların yönetimi zorlaşmakta ve morbidite, mortalite, hastanede yatış süre ve maliyetleri artmaktadır. Yapılan birçok çalışmada karbapenemaz-pozitif Enterobacteriaceae (KPE) üyelerinin endemik olduğu ülkelerde belirlenen başlıca risk faktörleri aşırı ve uygunsuz antibiyotik 
G. Altınkanat Gelmez ve ark., Erişkin Yoğun Bakım Ünitelerinde Karbapenem Dirençli Klebsiella pneumoniae ile Kolonizasyon/Enfeksiyon Gelişimi ve Karbapenemaz Tiplerinin Dağılımı

Tablo 1. Tarama kültürlerinden ve klinik örneklerden üretilen K.pneumoniae kökenlerindeki karbapenemaz genlerinin dağılımı.

\begin{tabular}{|c|c|c|c|c|}
\hline \multirow[b]{2}{*}{$\begin{array}{l}\text { Karbapenemaz } \\
\text { genleri }\end{array}$} & \multicolumn{2}{|c|}{$\begin{array}{l}\text { Tarama Kültürüü } \\
\qquad(n=51)\end{array}$} & \multicolumn{2}{|c|}{$\begin{array}{l}\text { Klinik Örnek Kültürü } \\
\qquad(n=30)\end{array}$} \\
\hline & $\mathrm{n}$ & $\%$ & $\mathbf{n}$ & $\%$ \\
\hline OXA-48 & 14 & 27.5 & 9 & 30 \\
\hline NDM & 10 & 19.6 & 6 & 20 \\
\hline KPC & 3 & 5.9 & 2 & 6.7 \\
\hline KPC+NDM & 4 & 7.8 & 1 & 3.3 \\
\hline OXA-48+NDM & 20 & 39.2 & 9 & 30 \\
\hline Neg & 0 & 0.0 & 3 & 10 \\
\hline
\end{tabular}

kullanımı, hastane yatış süresinde uzama, yoğun bakımda yatış, immünsüpresyon olarak tanımlanmıştır. Hastaların endemik olan bölgelere seyahati de bir risk faktörü olarak belirlenmiştir ${ }^{(15)}$.

Yoğun bakım hastaları arasında KPE'lerin gastrointestinal kolonizasyonu, yatan hastalar için büyük bir tehdit oluşturmaktadır. Hastaların florasında bulunan bu mikroorganizmalar o kişide endojen kaynaklı enfeksiyona neden olabildiği gibi bu patojenlerin diğer hastalara taşınmasında da rezervuar görevi görürler. Direncin önüne geçilmesinde ve yayılımlarının engellenmesindeki en önemli adım yoğun bakıma girişte rektal sürüntü örneklerinin alınarak kolonize hastaların tespiti, temas izolasyonu, tıbbi cihazların temizliği ve dezenfekte edilmesi ve antimikrobiyal yönetim programlarının oluşturulmasıdır.

YBÜ'lerinde ciddi invazif girişimlerin (mekanik ventilasyon, sonda takılması, damar içi kateterler, kardiyovasküler monitörizasyon, parenteral beslenme, immunsupresif tedaviler) sıklıkla yapılması ve hastaların savunma mekanizmalarının azlığı nedeniyle nozokomiyal patojenler hızla kolonize olurlar. Çalışmamızda yoğun bakım ünitelerimizde OXA-48 ve NDM türü enzimler en sık karşılaşılan karbapenemazlar olmakla beraber her iki enzim de \% 60 'lar düzeyinde saptanmıştır. Ayrıca daha önceki yıllarda gözlemlemediğimiz KPC tipi karbapenemazların hem tarama hem de klinik örneklerden azımsanmayacak oranlarda tespit edilmesi de bu enzimlerle daha sık karşılaşacağımızı düşündürmetedir. Çalışmamızda karbapenemaz-pozitif K. pneumoniae kolonizasyon oranımız \% 14.8 olarak
Tablo 2. Tarama yapılan hastalarda karbapenem dirençli K.pneumoniae'ye bağlı enfeksiyon gelişimi.

\begin{tabular}{|c|c|c|c|c|c|}
\hline & \multicolumn{2}{|c|}{ Tarama (+) } & \multicolumn{2}{|c|}{ Tarama (-) } & \multirow[b]{2}{*}{ Toplam } \\
\hline & $\mathrm{n}$ & $\%$ & $n$ & $\%$ & \\
\hline Enfeksiyon (+) & 17 & 33.3 & 4 & 1.3 & $21 *$ \\
\hline Enfeksiyon (-) & 34 & 67.7 & 289 & 98.7 & 323 \\
\hline Toplam & 51 & 100 & 293 & 100 & 344 \\
\hline
\end{tabular}

* Enfeksiyon gelişen 9 hastada tarama kültürü olmaksızın enfeksiyon saptandığından tabloya dahil edilmemiştir.

belirlenmiştir. Aktif sürveyans kültürlerinin düzenli aralıklarla yapılması yaygın enzimlerin ve direnç paternlerinin bilinmesi, bulaşın azaltılması ve enfeksiyon kontrol önlemlerinin etkinliğinin takip edilmesi açısından oldukça önemlidir. Çalışmamızda 1 hasta haricinde kolonize olan hastalarda gelişen enfeksiyonlarda benzer karbapenemaz türleri gözlemlenmiştir. Bu veri ampirik antibiyotik kullanımını yönlendirmek açısından da oldukça önemlidir. Çalışmamızın en önemli sınırlaması ise kolonizasyon ve enfeksiyondan sorumlu olan kökenler arasında klonal ilişkinin belirlenememiş olmasıdır.

McConville ve ark. ${ }^{(11)}$ yaptığı çalışmada rektal sürüntü örneği alındıktan sonra KPE kolonizasyonunun 30 gün içerisinde enfeksiyon gelişimi için güçlü bir prediktör olduğu, hastaların en az \% 50'sinde 30 gün içerisinde enfeksiyon geliştiğini ve kolonize olmayan hastalar ile kıyaslandığında enfeksiyon oranlarında \% 10.8 oranında artış olduğunu gözlemlemişlerdir. Çalışma sonuçlarımıza göre yoğun bakım ünitelerimizdeki kolonizasyon/enfeksiyon oranımız \% 33.3 olup kolonize hastaların yaklaşık üçte birinde enfeksiyon gelişebileceği belirlenmiştir. Bu mikroorganizma ile kolonize olduğu saptanan 17 hastada üç ay içerisinde enfeksiyon geliştiği tespit edilmiştir. Sadece 4 hastada tarama kültürleri negatif iken enfeksiyon geliştiği gözlemlenmiştir. Bu veriler doğrultusunda yoğun bakım ünitelerimizde KPE ile kolonize olan hastalarda enfeksiyon gelişme riskinin daha yüksek olduğu belirlenmiştir.

Karbapenemaz türlerinin epidemiyolojik dağılımının bilinmesi hem gelişmiş hem de gelişmekte olan ülkelerde alınan enfeksiyon kontrol önlemlerinin 
etkinliğinin ortaya konulması açısından önemli yarar sağlar. Rutin mikrobiyolojik yöntemlerle erken dönemde saptanmaları oldukça önemlidir. Enfeksiyon kontrol önlemlerinin alınmasındaki gecikmeler bu enzimlerin hızlı yayılmasına ve salgınların oluşabilmesini sağlamaktadır. Bu amaçla geliştirilen hızlı fenotipik testler rutin laboratuvarda bu enzimlerin tespitini kolaylaştırabilir. Çalışmamızda karbapenemazların fenotipik tespiti için kullanılan immunokromatografik yöntem sonuçları PCR sonuçları ile \% 100 uyumlu bulunmuştur. Bu veriler doğrultusunda bu test moleküler alt yapısı olmayan rutin laboratuvarlarda güvenle kullanılabilir.

Sonuç olarak karbapeneme dirençli Enterobacteriaceae enfeksiyonlarının gelişimi için risk faktörlerinin bilinmesi kadar klinik uygulamada direncin erken tanımlanması hem akılcı antibiyotik tedavisinin uygulanabilmesi hem de kolonize ve enfekte hastalarda uygun enfeksiyon kontrol önlemlerinin erken uygulanabilmesi için önem taşımaktadır.

Etik Kurul Onayı: Marmara Üniversitesi Tıp Fakültesi Klinik Araştırmalar Etik Kurulu'nun onayı alınmıştır. (01.09.2018/483)

Çıkar Çatışması: Yazarlar arasında herhangi bir çıkar çatışması yoktur.

Ethics Committee Approval: Approval of the Clinical Research Ethics Committee of Marmara University Faculty of Medicine was obtained. (01.09.2018 / 483)

Conflict of Interest: There is no conflict of interest between the authors.

\section{KAYNAKLAR}

1. Aktaş Z, Kayacan CB, Schneider I, Can B, Midilli K, Bauernfeind A. Carbapenem-hydrolyzing oxacillinase, OXA-48, persists in Klebsiella pneumoniae in Istanbul, Turkey. Chemotherapy. 2008;54(2):101-6.

2. Banach DB, Francois J, Blash S et al. Active surveillance for carbapenem-resistant Enterobacteriaceae using stool specimens submitted for testing for Clostridium difficile. Infect Control Hosp Epidemiol. 2014; 35(1):82-4.

3. Bhargava A, Hayakawa K, Silverman E et al. Risk factors for colonization due to carbapenem-resistant Enterobacteriaceae among patients exposed to longterm acute care and acute care facilities. Infect Control Hosp Epidemiol. 2014;35(4):398-405.

4. Calfee D, Jenkins SG. Use of active surveillance cultures to detect asymptomatic colonization with carbapenem-resistant Klebsiella pneumoniae in intensive care unit patients. Infect Control Hosp Epidemiol. 2008;29(10):966-8.

5. Cole JM, Schuetz AN, Hill CE, Nolte FS. Development and evaluation of a real-time PCR assay for detection of Klebsiella pneumoniae carbapenemase genes. J Clin Microbiol. 2009;47(2):322-6.

6. Dautzenberg MJ, Wekesa AN, Gniadkowski M et al. The association between colonization with carbapenemase-producing Enterobacteriaceae and overall ICU mortality: an observational cohort study. Crit Care Med. 2015;43(6):1170-7.

7. Debby BD, Ganor O, Yasmin M et al. Epidemiology of carbapenem-resistant Klebsiella pneumoniae colonization in an intensive care unit. Eur J Clin Microbiol Infect Dis. 2012;31(8):1811-7.

8. Dickstein $\mathrm{Y}$, Edelman R, Dror T, Hussein K, Bar-Lavie $\mathrm{Y}$, Paul M. Carbapenem-resistant Enterobacteriaceae colonization and infection in critically ill patients: a retrospective matched cohort comparison with noncarriers. J Hosp Infect. 2016;94(1):54-9.

9. European Committee on Antimicrobial Susceptibility Testing 2018. Breakpoint tables for interpretation of MICs and zone diameters Version $8.0 \mathrm{http}: / / w w w$. eucast.org/clinical_breakpoints

10. Lee CR, Lee JH, Park KS, Kim YB, Jeong BC, Lee SH. Global dissemination of carbapenemase-producing Klebsiella pneumoniae: epidemiology, genetic context, treatment options, and detection methods. Front Microbiol. 2016;13(7):895.

11. McConville TH, Sullivan SB, Gomez-Simmonds A, Whittier S, Uhlemann AC. Carbapenem-resistant Enterobacteriaceae colonization (CRE) and subsequent risk of infection and 90-day mortality in critically ill patients, an observational study. PLoS One. 2017;12(10):e0186195.

12. Papadimitriou-Olivgeris $\mathrm{M}$, Marangos $\mathrm{M}$, Fligou $\mathrm{F}$ et al. Risk factors for KPC-producing Klebsiella pneumoniae enteric colonization upon ICU admission. J Antimicrob Chemother. 2012;67(12): 2976-81.

13. Perry JD, Naqvi SH, Mirza IA, Alizai SA et al. Prevalence of faecal carriage of Enterobacteriaceae with NDM-1 carbapenemase at military hospitals in Pakistan, and evaluation of two chromogenic media. J Antimicrob Chemother. 2011;66(10):2288-94.

14. Pitout JD, Gregson DB, Poirel L, McClure JA, Le P, 
G. Altınkanat Gelmez ve ark., Erişkin Yoğun Bakım Ünitelerinde Karbapenem Dirençli Klebsiella pneumoniae ile Kolonizasyon/Enfeksiyon

Church DL. Detection of Pseudomonas aeruginosa producing metallo-beta-lactamases in a large centralized laboratory. J Clin Microbiol. 2005;43(7): 3129-35.

15. Risk assessment on the spread of carbapenemaseproducing Enterobacteriaceae (CPE) through patient transfer between healthcare facilities, with special emphasis on cross-border transfer. ECDC Technical Report (2011). https://ecdc.europa.eu/en/ publications-data

16. Tzouvelekis LS, Markogiannakis A, Psichogiou M, Tassios PT, Daikos GL. Carbapenemases in Klebsiella pneumoniae and other Enterobacteriaceae: an evolving crisis of global dimensions. Clin Microbiol
Rev. 2012;25(4):682-707.

17. Vidal-Navarro L, Pfeiffer C, Bouziges N, Sotto A, Lavigne JP. Faecal carriage of multidrug-resistant Gram-negative bacilli during a non-outbreak situation in a French university hospital. J Antimicrob Chemother. 2010;65(11):2455-8.

18. Wiener-Well Y, Rudensky B, Yinnon AM et al. Carriage rate of carbapenem-resistant Klebsiella pneumoniae in hospitalised patients during a national outbreak. J Hosp Infect. 2010;74(4):344-9.

19. Zhao ZC, Xu XH, Liu MB, Wu J, Lin J, Li B. Fecal carriage of carbapenem-resistant Enterobacteriaceae in a Chinese university hospital. Am J Infect Control. 2014;42(5):e61-4. 